\title{
RISK AND UNSUSTAINABILITY IN VILLAHERMOSA, MEXICO
}

\author{
JOEL F. AUDEFROY \\ Instituto Politécnico Nacional (IPN) Escuela Superior de Ingeniería y Arquitectura (ESIA-Tecamachalco), Mexico
}

\begin{abstract}
The city of Villahermosa, Tabasco, Mexico is located in the basin of the Grijalva and Usumacinta rivers. In pre-Hispanic times, the watershed system was not a threat; rather, it was a system that favored human settlements and trade. Since then, throughout its history, the plain has undergone several transformations that have changed its riverbeds. Urban development plans and the design and control of water works have failed to take these changes into account, forgetting that rivers have memory and tend to return to their old channels. Historically, between 1652 and 2008 floods and disasters caused by hydrometeorological events on record totaled 67 events. In the period for which we have reliable records of hydrometeorological events, recurrent flooding has been observed, especially in the months of September, October, and November. In that context, the great flood of October 2007 cannot be seen as an isolated phenomenon. This study shows how, over time, the risk of flooding in Villahermosa has been socially constructed by human actions that undermine sustainability: the diversion of rivers, deforestation, and introduction of livestock, all of which have contributed to changing ecosystems and the hydrogeological context of the state. Despite extensive water works carried out since the 1950s, the city of Villahermosa remains highly vulnerable to catastrophic flooding. There are irregular settlements which are particularly vulnerable to flooding, due to the absence of a policy on low-income housing development. The "modernization" of Tabasco has been promoted since the 1960s, and is another example of the social construction of risk, resulting in damage to ecosystems and the deterioration of living conditions of broad sectors of the population. The cost of these development policies was very high. Shantytowns on the riverbanks and floodplains are a long-term consequence of modernization and neoliberal policies in place since the 1980s, which ignored the need for policies to ensure sustainability.
\end{abstract}

Keywords: human settlements, flooding, risk, sustainability.

\section{INTRODUCTION}

In pre-Hispanic times, the basin of the Grijalva and Usumacinta rivers was a propitious location for the development of agriculture and a water-based civilization, as water works built by the indigenous Chole and Chontal Mayan cultures attest. In those times, the hydrological basin system was not a threat; rather, it favored human settlements and commercial exchange. Before the Spanish conquest, the area's inhabitants had created a river and coastal navigation network which permitted trade from the Central Mexican Plateau to Honduras and Guatemala. The arrival of Juan de Grijalva on June 8, 1518, the landing of Hernan Cortes in 1519 in the village of Potonchan, and the ensuing battle with the Chontal Maya on the plains of Centla, marked the beginning of the Spanish conquest and the exploitation of the basin. In the colonial period, Tabasco saw a boom in exploitation of its abundant mahogany. The Spaniards found a way to approach from the riverbanks and start clearing the forests. Over the years, such exploitation advanced, clearing the way for new settlements further inland. Later, the exploitation of gum-producing sapodilla trees ended the first stage of the environmental devastation of the Tabasco jungle.

Throughout its history, the Tabasco plain has undergone several transformations which have altered the riverbeds. Such changes have not been taken into account by urban 
development plans and by the design and control of planned water works, forgetting that rivers have memory and tend to return to their former beds.

Originally, the most densely populated region was Chontalpa, which was home to the Chontal Maya, between the Rio Seco and Rio Nuevo rivers. Many settlements sprung up along their shores to gain direct access to river-going vessels. In the 17th Century, in response to incursions by pirates entering through Dos Bocas Bay and following the Mezcalapa River to attack towns at a considerable distance from the coast, in 1675 the inhabitants of Cardenas diverted the river to the east, blocking communication to Dos Bocas and drying the river (Rio Seco) to deny the pirates their means of access, producing an artificial "trench" of unforeseen consequences by diverting all the water to the arm passing through San Juan Bautista on the site of present-day Villahermosa and causing further flooding. The former bed of the Mezcalapa passing through Paraiso and Comacalco would be known from that time forth as Rio Seco [1].

The river which was formed has been highly unstable in its line of flow because its channels lack depth. First, it was channeled through Rio Viejo and joined Rio Sierra south of Villahermosa, forming the Grijalva River between the two. This resulted in massive floods in the city of Villahermosa.

Starting in 1955, a series of actions were taken, among them damming the Viejo Mezcalapa River to reduce flooding in Villahermosa, and the construction of a series of embankments, canals, and drains to prevent flooding.

The Grijalva River is controlled primarily by a system of hydroelectric dams; the other river, the Usumacinta, has no such dams to control it. We can estimate a frequency of exceedance of two events every ten years for rainfalls of more than $500 \mathrm{~mm}$ and 1.33 events every ten years for rainfalls of more than $700 \mathrm{~mm}$ [2]. Thus, we can observe a recurrence of flooding, especially in the months of September, October, and November. Consequently, the October 2007 flood was not an isolated phenomenon (Fig. 1).

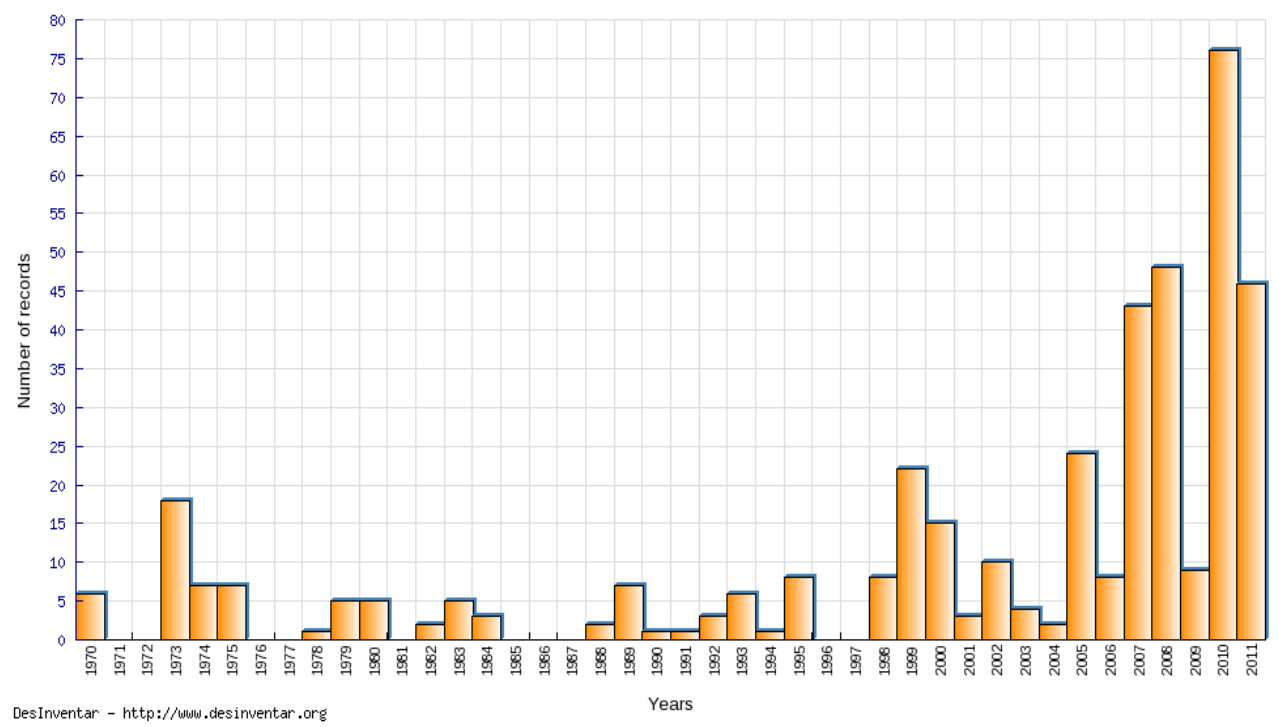

Figure 1: Number of floods in the State of Tabasco in the period 1970-2011. (Source: http://online.desinventar.org/.) 
The historical data shows how, over time, the risk of flooding in Tabasco has been socially constructed by anthropic actions: the diversion of rivers, felling of trees, and introduction of livestock, which have caused changes in the state's ecosystems and hydrogeological context. In the decade 1940-1950, deforestation attained an intensity never before seen in the region [1]. The state's area of forest cover fell from $49 \%$ in 1940 to $38.5 \%$ in 1950 . Forest cover was seen as an obstacle to the development and modernization of the farming sector. The unanticipated consequences were dramatic: erosion, drought, loss of nutrients from soils, and heightened vulnerability to pests, in addition to the irreversible disruption of the ecological balance.

The advance of works in the lower Grijalva basin intensified, starting in 1955, and in 1957 the "Lower Grijalva River Irrigation, Drainage, and Flood Control District" was created. As we can see, such efforts have failed to effectively control the floods that ensued through the 1950s, 1960s, 1970s, and 1980s, leading to the great floods of 1999 and 2007.

\section{THE OCTOBER 2007 DISASTER}

The October 2007 disaster resulted in 1 million people being affected by flooding, as reported by the state government, and more than 350,000 lost all their belongings. Around $70 \%$ of the territory was flooded, causing 31.871 billion pesos in damages and losses, equal to nearly $30 \%$ of the Gross State Product (GSP) for the same year [3]. Between 2007 and 2012, the state of Tabasco made requests to the FONDEN (Natural Disaster Relief Fund) and FOPREDEN (Natural Disaster Prevention Fund) for the amounts shown in Table 1.

The disaster started October 29, 2007, after four days of heavy rains caused by the presence of two cold fronts. On October 28, a weather station in Ocotepec, Chiapas, recorded $403 \mathrm{~mm}$ of rainfall, followed by $309 \mathrm{~mm}$ the next day, and $205 \mathrm{~mm}$ on October 30 . The cumulative total for those three days was $962.8 \mathrm{~mm}$, and reports confirmed six more rainfalls above the historical record from 1941. While these figures indicate the scale of the natural phenomenon, they do not explain the disaster on their own. The situation on the ground was uncontrollable due to runoff from the Peñitas reservoir, which was at $90 \%$ of its capacity. Eighty percent of the city of Villahermosa was flooded. The Grijalva River reached a height of $7.14 \mathrm{~m}, 2 \mathrm{~m}$ above its critical scale. Low-income districts like Las Gaviotas, La Manga, and downtown Villahermosa were under $2 \mathrm{~m}$ of water.

\section{THE "NATURAL" AND MAN-MADE CAUSES OF THE FLOODS}

In its report on the 2007 floods in the state of Tabasco (March 2008), the Mexican Senate's Commission on Water Affairs attributes the floods to various causes of natural origin, such as cold fronts (No. 4 and No. 5) which caused extraordinary rainfall in excess of $400 \mathrm{~mm}$ in

Table 1: Amounts of FONDEN and FOPREDEN in Mexican pesos.

\begin{tabular}{|l|l|l|}
\hline & \multicolumn{2}{|l|}{ Amounts (millions of pesos) } \\
\hline Year & FONDEN & FOPREDEN \\
\hline 2007 & 1,645 & \\
\hline 2008 & 2,316 & 4 \\
\hline 2009 & 2,591 & 38 \\
\hline 2010 & 582 & \\
\hline 2011 & 4,069 & \\
\hline 2012 & 3,013 & 132 \\
\hline Total & 14,219 & 176 \\
\hline
\end{tabular}

Source:Fernando Aragón-Durand, 2012. 
24 hours and nearly $1000 \mathrm{~mm}$ in three days (October 28-30) in the Grijalva River De la Sierra River basin. Aside from the immediate causes triggered by the cold fronts, the Commission recognizes other factors of man-made origin such as the high vulnerability of certain districts of Villahermosa (like Las Gaviotas and the right shore of the De la Sierra River) located in risk zones; a lack of control infrastructure on the De la Sierra and Usumacinta rivers, including the PICI (Comprehensive Flood Control Program) which, at the time of the flood, had not completed some planned works; lack of a better early warning and weather forecasting system; and lack of a comprehensive flood management plan.

The cold front was merely a "precipitating" factor, and it is as or more important to consider other factors within a long process of risk construction which has been in motion since earlier historical periods. Although climate change is also a factor to consider, it does not provide a complete explanation of the events. There is a combination of risks and vulnerabilities which have developed gradually, through an accumulation of errors, blind decisions, works (filling swamps and lagoons, disappearance of regulating reservoirs) and hydrological changes which have affected the environment of the Grijalva River basin.

We need to look back to the year 1999, when a series of equally "surprising" floods affected 300,000 people and covered around $70 \%$ of Villahermosa due to flooding of the Carrizal River. At the time, it was decided to reinstate the PICI created in 1996 by several institutions like the CONAGUA (National Water Commission), the CFE (Federal Electricity Commission), the UNAM (National Autonomous University of Mexico) Institute of Engineering, and the IMTA (Mexican Water Technology Institute). These studies, in turn, produced the "Great Vision Project," which comprised three main systems: the Mazcalapa-Samaria; the Carrizal-Medellin, and the De la Sierra rivers. The first two enter Villahermosa from the west and the third from the east. The project, in the words of the state government, "represents protection for more than 300 thousand inhabitants and covers a total of 46 thousand hectares of urban, rural, and productive zones, offering flood protection in case of extreme hydrometeorological events" [4]. Among the studies conducted between 1996 and 2002, there were plans for the construction of 24 principal works to be completed in four years, with the federal government contributing $72 \%$ of the necessary funding and the state government the rest. These are the five major projects which were not executed:

- Desilting of the rivers of the Grijalva Basin (Tabasco-Chiapas);

- Real situation of the Upper Grijalva dam system;

- Behavior of tides at the mouths of the rivers on the Gulf coast;

- Removal of settlements on the riverbanks;

- Creation of $120 \mathrm{~km}$ of retaining walls in the city.

Four projects were only partially completed, as follows:

- Control structure on the Carrizal River (northwest Villahermosa);

- Control structure on the La Serra and Pichucalco rivers;

- Embankment on the left shore of the Grijalva River;

- Straightening of the beds of the Medellin Dren Victoria rivers.

In late 2006, the PICI had achieved 70\% completion, as reported by the CONAGUA, in its three systems (Mazcalapa-Samaria; Carrizal-Medellin; and the De la Sierra rivers). It bears mention that the PICI's work can be reduced, basically, to the construction of water works, and has not included - despite plans for their implementation - other necessary measures like the regulation of landholdings. Water works are not the only solution to mitigate future flooding and the $70 \%$ progress reported by the CONAGUA proved insufficient to prevent flooding in 2007. 
Table 2: Maximum rainfalls in the Peñitas and De la Sierra River basins in mm. (Source: 2007 Report on flooding in the state of Tabasco, March 2008.)

\begin{tabular}{|l|l|l|l|l|}
\hline Basin & October 28 & October 29 & October 30 & October 31 \\
\hline Peñitas & 403.4 & 308.9 & 250.5 & 100.3 \\
\hline De la Sierra rivers & 317.0 & 249.6 & 152.0 & 32.5 \\
\hline
\end{tabular}

Another possible man-made cause of flooding was the hypothesis of the mismanagement of the Peñitas Reservoir, on the upper Grijalva River upstream from Villahermosa. According to the complainants, the federal authorities responsible for the reservoir (CONAGUA, CFE, and the state government) ignored weather forecasts and continued to run the turbines at low volume on October 25-28, 2007, allowing the reservoir to reach a critical level of 90.06 masl and causing the disaster in Villahermosa. The maximum rainfalls recorded in the Peñitas and De la Sierra rivers were on October 28-31, as shown in Table 2.

The Senate Commission determined and concluded that the reservoir was operated in accordance with established procedures and that the flood was caused by the severity of the intense rainfall; however, those procedures resulted in a disaster. On October 23-29, the turbines were operated at average volumes on the order of $476 \mathrm{~m}^{3} / \mathrm{s}$. Had they been run at $910 \mathrm{~m}^{3} / \mathrm{s}$, as they were in January 2007, under comparable circumstances, the reservoir would have remained at 85.93 masl instead of the 90.06 masl reported on October 29.

In conclusion, the causes of flooding in Tabasco are numerous and respond to the functioning of a complex system. There was an accumulation of decisions, events, and circumstances, most man-made, which combined with hydrometeorological events to produce the disaster.

\section{THE VULNERABILITY OF HOUSING IN VILLAHERMOSA}

In the aftermath of the floods in the years 1980, 1995, and 1999, and the most recent in 2007, areas especially vulnerable to flooding have been identified, most on the outskirts of Villahermosa in the vicinity of the De la Sierra and Carrizal rivers. In those areas, there are regular and irregular settlements, including the villages of Torno Largo, Coquitos, Valle Verde, and Armenia and the La Gaviotas Sur and Gaviotas Norte and La Manga I, II, and III districts. On the left bank of the De la Sierra River, the Casa Blanca I and II districts, and part of downtown Villahermosa have also been affected.

Existing patterns of land use makes these areas extremely vulnerable to flooding. Urbanization is concentrated in low-lying areas and flood plains. There is also severe deforestation and lack of control infrastructure on occupied plots in the upper section of the Grijalva River basin. There is no scientific data available on the effects of deforestation on the rainfall-runoff ratio, on the process of erosion and sedimentation, and on the resulting silting of riverbeds. We know only the effects. Historically, the change in land use from forest to farming has been the first ecological rupture. Traditional farming practices (clearing, burning, and felling) on sloping riverbanks have transformed them into heavily eroded areas as a result of heavy rains. This situation, in turn, produces large quantities of silt which accumulates in the riverbeds, reducing their carrying capacity over time. The increased water column due to the buildup of silt in riverbeds with limited slope favors the weakening of their banks, leading to the collapse and blockage of the stream.

The growing urban sprawl in Municipio Centro (Villahermosa) has gone from 3227 hectares in 1984 to 6484 in 2008 . We can see how growth has doubled in only 14 years, at a rate of 234 hectares/year. Between 1984 and 2000 the city of Villahermosa grew 38.65\% in total area. Localities like Las Gaviotas grew 200\%. The type of land use combined with urban growth is creating conditions for future disasters. 
Another phenomenon which further exacerbates the vulnerability of Municipio Centro is the presence of irregular settlements. Villahermosa's growth was unplanned, due to a lack of urban policy and the absence of regulatory instruments. Thus, today there are several irregular settlements in different parts of the municipality. The Municipio Centro Directorate of Public Works presents a map of some 59 settlements which have not been regularized, which have developed as the result of invasion by squatters or the illegal sale of lots. Some of them are located in flood zones.

Based on the information published in the Municipio Centro Risk Atlas (2009), taken from surveys applied in the 31 districts of Municipio Centro comprised within high-risk zones, we find that the physical conditions of homes make them especially vulnerable to flooding, not only due to the materials used, but also due to their typology and morphology.

We can distinguish six types of homes, classified by materials and structural features (Table 3).

Type I and II homes are highly vulnerable to flooding because they lack the material and structural elements which help them withstand the effects of water. Usually, such homes are destroyed by heavy rains and floods and cannot reoccupied. In fact, many families who lived in this type of homes in 2007 are now in rebuilding programs. Such families also lost all their belongings.

Also, type I, II, and III homes have only one story (ground floor), making them even more vulnerable to flooding. Type IV+ homes mostly have more than one story, allowing their occupants to keep their belongings safe on upper levels. The percentage of homes with one or more stories is shown in Table 4.

The Municipio Centro Risk Atlas identifies 10 districts in the Municipality with very high hydrometeorological risk, as shown in Table 5.

We can see that a total of 46,488 inhabitants are at high hydrometeorological risk on 403 hectares. In other words, these ten districts are perfectly identified by the local authorities and may be targeted by rebuilding or neighborhood plans in view of the high vulnerability of housing there. Also, the Risk Atlas identified 25 high-risk districts which are protected (for how long?) by retaining walls erected following the 1999 flood. The same analysis also found that around 19 districts, such as INVITAB Miguel Hidalgo and El Triunfo La Manga, with a population density of $10 \mathrm{mil}$ inhabitants $/ \mathrm{km}^{2}$, are at medium risk.

Table 3: The classification of homes located in high-risk zones and their respective percentages. (Source: Municipio Centro Risk Atlas, 2009.)

\begin{tabular}{|l|l|l|}
\hline Type & Description & $\%$ \\
\hline I & A single room built from scrap or non-permanent materials & 5.72 \\
\hline II & $\begin{array}{l}\text { Masonry and cement floors, without structural elements, with } \\
\text { roofing of galvanized sheet metal or asphalt-saturated felt board }\end{array}$ & 13.02 \\
\hline III & $\begin{array}{l}\text { Masonry walls, asbestos roofing, some structural elements, and } \\
\text { tile floors }\end{array}$ & 10.41 \\
\hline IV & $\begin{array}{l}\text { Masonry walls, concrete slab roofing, and integrated structural } \\
\text { elements }\end{array}$ & 45.83 \\
\hline V & $\begin{array}{l}\text { Lower-income housing built with professional supervision } \\
\text { VI }\end{array}$ & Residential, built with professional supervision \\
\hline
\end{tabular}


Table 4: Percentage of one or more story homes. (Source: Municipio Centro Risk Atlas, 2009.)

\begin{tabular}{|l|l|l|l|l|}
\hline Type/no. of stories & $\mathbf{1}$ story & $\mathbf{2}$ stories & $\mathbf{3}$ stories & $\mathbf{4}$ stories \\
\hline I & 100 & 0 & 0 & 0 \\
\hline II & 96 & 4 & 0 & 0 \\
\hline III & 95 & 5 & 0 & 0 \\
\hline IV & 29.54 & 65.90 & 4.54 & 0 \\
\hline V & 45.94 & 40.54 & 5.40 & 8.12 \\
\hline VI & 18.18 & 81.81 & 0 & 0 \\
\hline
\end{tabular}

Table 5: Districts classified as having very high hydrometeorological risk in Municipio Centro, Villahermosa. (Source: Municipio Centro Risk Atlas, 2009.)

\begin{tabular}{|l|l|l|l|}
\hline Districts & No. of inhabitants & Density & Area (has) \\
\hline Triunfo la Manga I Subdivision & 2216 & 17,046 & 0.13 \\
\hline Gaviotas Sur District, San Jose Sector & 13,682 & 15,893 & 52.00 \\
\hline $\begin{array}{l}\text { Gaviotas Norte District, Esplanade } \\
\text { Sector }\end{array}$ & 2205 & 13,119 & 1.16 \\
\hline Triunfo la Manga III Subdivision & 641 & 12,290 & 1.31 \\
\hline La Manga II District, stage [... & 6809 & 7755 & 18.04 \\
\hline $\begin{array}{l}\text { Jose Maria Pino Suarez (Tierra } \\
\text { Colorada) District }\end{array}$ & 8058 & 7348 & 8.27 \\
\hline Gaviotas Sur Armenia District & 3631 & 4421 & 36.76 \\
\hline Casa Blanca District 1st Sect. & 3064 & 2691 & 62.10 \\
\hline Casa Blanca District, 2nd Sect. & 4619 & 1488 & 189.14 \\
\hline Sabina District & 1563 & 388 & 34.87 \\
\hline Total & $\mathbf{4 6 , 4 8 8}$ hab. & & $\mathbf{4 0 3 . 7 8 ~ h a s . ~}$ \\
\hline
\end{tabular}

\section{SOCIAL AND ECONOMIC VULNERABILITY}

To evaluate social and economic vulnerability, six fundamental variables were taken as reference, including healthcare, education, housing, employment and income, population, and economic activities:

- Healthcare: vulnerability is very low, because there is a favorable ratio of doctors to inhabitants, low infant mortality, and a very small percentage of people without access to healthcare services.

- Education: of the 206 localities comprising the municipality, only three had a zero average.

- Housing: In general, the percentage of homes without utilities and with precarious materials is low, but we have seen that the percentage is higher in very high-risk districts. 
- Employment: Sixty percent of the active population earns more than double the minimum wage and are, therefore, classified as having a low vulnerability. However, some districts like Pablo L. Sidar and Estancia Vieja 1st and 2nd sections are in a greater state of vulnerability. Forty percent of the active population has very low income, less than double the minimum wage, making that sector of the population highly vulnerable.

- Population: the average population density in Municipio Centro is 334 inhabitants per $\mathrm{km}^{2}$, putting it among the highest in the state. Ten percent of the population lives in municipalities with under 2500 inhabitants, which constitutes a factor of vulnerability in case of emergency.

- Economic activities: The economically active male population represents the majority. The per capita GDP is above the national mean due to the oil industry. The total per capita current income (Spanish acronym ICTPC) is relatively low (MX\$2199 in 2010) and below the national average. In the period 2008 to 2010 we observed a drop in Tabasco's average ICTPC, going from MX\$2406 to MX\$2199, whereas the national average was MX\$3059.7 in 2008 and MX\$2915.8 in 2010. This represents a drop in the income level of the state's inhabitants.

Although Municipio Centro is in a situation of low socioeconomic vulnerability based on the analysis results published in the Risk Atlas, there are neighborhoods and districts with very high social vulnerability which do not appear in the study, which used data only at the municipal level. The results show that education is the variable which scored the highest, indicating higher vulnerability.

Although the condition of housing in terms of utilities is good at the municipal level, high-risk districts report less favorable results, which, combined with a $40 \%$ sector of the population earning less than double the minimum wage, places that population in a situation of high vulnerability, with a very low capacity for response and adaptation. Consequently, we do not concur with the results of the analysis presented in the Risk Atlas, which classifies Municipio Centro as a low-vulnerability area. We cannot agree with the following affirmation: "In general terms, Municipio Centro is a municipality with a low level of social vulnerability, both overall and in its different spatial units, with a population which, from a social and economic standpoint, is fairly homogeneous." In fact, the rebuilding program implemented after the 2007 floods contradicts this opinion, because the program was designed for families with very limited means who had lost their belongings and their precarious homes, contradicting the characterization of a "fairly homogeneous" population. The population of Municipio Centro is especially heterogeneous due to its location within the city, types of housing, and economic means ( $49.7 \%$ below the poverty line). In conclusion, the Risk Atlas, due to its erroneous interpretation, cannot offer much help in preventing future hydrometeorological events.

\section{6 “ADAPTED” REBUILDING}

In the 1970s and 1980s, during the oil boom years, Villahermosa grew, and part of its growth extended to the north and northeast of the city. The first districts to form were Las Gaviotas and La Manga on communal lands located to the east of the city. By the 1990s, those districts had grown and consolidated; however, at the time of the 2007 flood, a number of precarious homes remained. The land they occupied is prone to flooding during the rainy season, and for that reason the price of lots was relatively low. According to the Municipio de Centro Risks Atlas (2009), the municipality has a total population of 53,759 inhabitants, of whom 30,283 are highly exposed to danger of flooding and 23,476 are moderately exposed. 
The Las Gaviotas district covers an area of 62.55 hectares with a population density of 78.1 inhabitants/hectare, which is relatively low for a low-income district. The constructions are consolidated low-income type, the majority of homes having one or two stories. We found only one house with piles in our tour of Las Gaviotas.

Las Gaviotas is a low-income district where many families rented homes at the time of the 2007 flood and were subsequently relocated. Most of the families who owned homes and lived in Las Gaviotas returned. Those who rented homes were eager to acquire homes of their own and for that reason agreed to stay in shelters despite the rigid rules imposed by the Municipality. They stayed in shelters for almost 10 months with the promise that they would be given homes. Of the 378 families in shelters, 72 lived on riverbanks, 147 rented (mainly in Las Gaviotas or La Manga) and 159 lived in loaned homes. The homes they leased or occupied on loan were usually precarious, with one room serving as kitchen, dining room, and bedroom. In fact, those families had no practices for the prevention or mitigation of flooding.

After a long stay at the Parque Recreativo de Altasta shelter, on August 19, 2008, 388 families arrived at the first subdivision created, Gracias Mexico, located at km 18 on the Villahermosa-Teapa highway. The subdivision was made by the state government (INVITAB, Tabasco State Housing Institute) in a joint effort with the National Housing Commission (CONAVI) and the Provivah trust, a private foundation which received tax-deductible donations, mainly from private companies. Here it should be noted that the subdivision was not developed with funds from FONDEN because the fund's rules required that it rebuild on the same site the affected families had occupied previously, and in this case the families had no property (rented or loaned housing) and it would have been counterproductive to rebuild on the same site at risk of flooding. Thus, the state government made the decision to build the subdivision on a supposedly safer site. Most of the people who moved there came from the Las Gaviotas district (in its different sectors), and to a lesser extent from La Manga, Tierra Colorada, and Emiliano Zapata, among others.

In a second stage, a second subdivision was built, called 27 de octubre, at $\mathrm{km} 15$ on the same Villahermosa-Teapa highway, for 343 families from the Casa Blanca district who had also suffered flooding and had lost their homes or remained at high risk. A total of 885 homes were built. The third stage was developed after the Ciudad Bicentenario subdivision was built on the same highway, with a total of 3724 homes of different types.

\section{CONCLUSIONS}

We can observe, in a diachronic cross section, a series of anthropogenic actions from the time of the Spanish conquest, with the diversion of the Grijalva River, to the present day, which have had considerable impact on the environment and ecological balance of the region.

In a not too distant past, Tabasco's inhabitants understood nature and hydrometeorological phenomena as an element of the environment with which they lived in close contact, adapting to its characteristics, both in their way of life and in their forms of production. This man-environment relationship also has an important historical and cultural meaning for the local population because, to date, there are rural or rural-urban communities intricately linked to water not only as a means of transport, but as a source of supply for human consumption and to cultivate the seasonal flood plains. Rural populations knew that they needed to build their homes on higher ground or on stilts to withstand the effects of flooding. This way of life and its customs have changed with the advent of modern agriculture, industry, and supposed "development." 
Starting in the 1960s with the construction of dams in Chiapas, the behavior of the region's rivers and their beds gradually changed. As a result, the local populations also made major changes in their perception of risk and their relationship with nature:

- With the flow of rivers lessened due to control by dams, the population perceived a reduced risk and began to populate the riverbanks without the authorities recognizing the social construction of risk and the resultant unsustainability of the city;

- As the different species which inhabited the rivers disappeared, due to diminished flows, change, or over-exploitation, the rivers and regulating reservoirs which constituted part of their habitat began to lose value in the eyes of the community and were gradually abandoned;

- As the riverbanks were populated, the quantity of waste dumped into streams increased, with sewage discharged into the streams, pollution increased considerably and irresponsibly. Thus, the rivers came to be seen as deposits for sewage and refuse, causing further flooding.

A study conducted by the CODEHUCO in 2011 [5] on perceived risk found that more than $70 \%$ of the population of the Comacalco region associates the risk of flooding with rivers and heavy rainfall, and have a minimal perception of the risk dams pose to the population, and inhabitants are much less aware that the management of those dams has been the leading cause of change in the behavior of the region's rivers and the most recent floods in the state.

On the one hand, we have human actions in the state of Tabasco which have contributed to the social construction of risk, but on the other hand we need to consider the associated climatic factors to determine the possible effects of climate change in the state. A study conducted almost 30 years ago (1986) by Fernando Tudela [1] arrived at the following conclusions on this topic:

"Although we cannot affirm that large-scale climate change has occurred in the recent period, we can confirm that there have been significant changes at the level of microclimates. deforestation and hydrological alteration are the primary factors in triggering micro-climate change. The monthly averages used to define climates do not reflect daily and periodic fluctuations at micro-climate scale. The destruction of forests eliminates the vertical differentiation of temperature between the different plant strata. Also, fluctuations in temperature occur in wider ranges, especially due to higher maximum temperatures."

According to a prospective study by the IMTA (2010) [6], annual precipitation in the state of Tabasco will drop from $2043 \mathrm{~mm}$ to $1716 \mathrm{~mm}$ between the years 1990 and 2090 . However, the average annual mean temperature will increase from $26.45^{\circ} \mathrm{C}$ to $29.8^{\circ} \mathrm{C}$ in the same period and the maximum summer temperature will increase from $28.21^{\circ} \mathrm{C}$ to $32.3^{\circ} \mathrm{C}$. These figures are for the entire state, and if we consider microclimates the resulting data could be different. The inhabitants of Villahermosa seem to perceive some measure of climate change, because they remark that the dry season is longer than before and the temperatures are higher.

We also observed that the PICI was a failure, and its reboot, the Tabasco Comprehensive Water Plan (PHIT) is moving forward slowly. But such plans seek to control flooding produced by superstructures supposedly built as part of a comprehensive development plan for the state, i.e. the Chontalpa Plan. If there are plans and actions to build new infrastructure, embankments for example, we have not seen any mitigating measures, except in cases of emergency when the army piles sandbags along the riverbanks. Mitigation is not necessarily 
an infrastructure project; it may be included in the design of the risk atlas, in the Urban Development Plan, in local building codes for lower-income housing developers, in manuals published for at-risk populations, etc. What we definitely have not observed are processes of adaptation; in particular, in lower-income housing programs.

The "modernization" of Tabasco starting in the 1960s, which is another form of social construction of risk, resulted in damage to ecosystems and worsening living conditions for broad sectors of the population [1]. The cost of these development policies was high. The precarious settlements which emerged along the riverbanks and in flood zones are a long-term consequence of modernizing policies and, thus, of neoliberal policies implemented since the 1980s.

It is interesting to observe that, on the one hand, we see the high physical and social vulnerability of populations to hydrometeorological events, and on the other, the first effects of climate change, perhaps at a microclimate level; but the data we obtained through the desinventar database show an increase in flooding statewide since the year 2005, which could confirm longer drought cycles and abundant rainfall in a shorter time, causing the rivers to overflow. The future of Tabasco and Villahermosa is under the sign of the rain god Tlaloc if water policies and urban development plans are not changed to favor more sustainable alternatives. In reality, such a change is possible considering the high revenues produced by the oil industry in Tabasco.

\section{ACKNOWLEDGEMENT}

This investigation received financial support from the Secretaria de Posgrado (SIP) of the Instituto Politécnico Nacional (IPN), Mexico, and COFAA.

\section{REFERENCES}

[1] Tudela, F. (coord.), La modernización forzada del trópico: el caso de Tabasco, Proyecto integrado del Golfo, COLMEX-CINVESTAV-IFIAS-UNRISD, México, 475 pp., 1989.

[2] Galindo Alcántara, A., Atlas de riesgo del municipio de centro, Programa Hábitat de la Secretaria de Desarrollo Social, SEDESOL, IMPLAN, UJAT, Villahermosa, 191 pp., 2009.

[3] Senado de la República, Informe de las inundaciones de 2007 en el Estado de Tabasco, diagnóstico preliminar, IMTA/IPN/Colegio de posgraduados/UNAM, México, 48 pp., 2008.

[4] Villegas Villamil, A., Tabasco: Negligencia Criminal, s/e, 119 pp., 2009.

[5] Comité de Derechos Humanos de Comalcalco A.C., (CODEHUCO), "A los años mil, el agua vuelve a su carril..." Estudio sobre los Factores de riesgo de desastre por inundaciones en el municipio de Comalcalco, Tabasco, Comacalco, 68, pp. 2011.

[6] Martínez Austria, P.F. \& Patiño Gómez, C. (coords), Atlas de vulnerabilidad hídrica en México ante el cambio climático. Efectos del cambio climático en los recursos hídricos de México, Vol. III, IMTA, Jiutepec, Mor., 2010. 